\title{
Farming as a performance: a conceptual and methodological contribution to the ecology of practices
}

\author{
Dominic Glover ${ }^{1}$ \\ Institute of Development Studies at the University of Sussex, UK
}

\begin{abstract}
In two widely cited articles, the first of which was published almost 30 years ago, the anthropologist Paul Richards described the situated practices of small-scale farmers as a type of performance, akin to a musical or theatrical performance $(1989,1993)$. This definition, applied specifically to small-scale and subsistence agriculture, has a powerful appeal for good reasons. This article examines performance as a conceptual framework and tool for studying small-scale farming practice and technological change. Taking the comparison with musical or theatrical endeavour seriously, the article explores the dynamics of performance by individuals and groups; considers alternative ways of conceiving the 'stage' and the 'audience'; and examines the nature of the performers' skills and competence, through an elaboration of key concepts such as practice, rehearsal, repertoire and improvisation. The article also discusses the important implications of a performance being situated in a particular time and place, shaped by its surrounding socio-cultural and ecological context and conditioned by uncertainty. The article proposes that ethnographic or technographic methods are appropriate for studying performance, and considers the ethical responsibilities of the researcher when intervening in a performance from its outside. The argument is framed as a contribution to political ecology, especially an ecology of practices.
\end{abstract}

Key words: Performance, farming, practice, skill, technography

\section{Résumé}

L'anthropologue Paul Richards, dans deux articles souvent cités (un publié il y a près de 30 ans), a décrit les pratiques des petits agriculteurs comme un type de performance, s'apparentant à une performance musicale ou théâtrale $(1989,1993)$. Cette définition, qui s'applique spécifiquement à l'agriculture de petite taille et de subsistance, a un attrait puissant - pour de bonnes raisons. Cet article examine «la performance» en tant que cadre conceptuel et outil pour étudier les pratiques agricoles à petite échelle et le changement technologique. Pour prendre au sérieux la comparaison avec l'effort musical ou théâtral, l'article explore la dynamique de la performance par des individus et des groupes; considère d'autres manières de concevoir «la scène» et «le "public»; et examine la nature des aptitudes et compétences des interprètes. Je le fais en élaborant des concepts clés tels que pratique, répétition, répertoire et improvisation. L'article aborde également les implications importantes d'une représentation se situant dans un lieu et une époque donnés, façonnée par le contexte socioculturel et écologique qui l'entoure et conditionnée par l'incertitude. L'article propose que les méthodes

\footnotetext{
${ }^{1}$ Dr. Dominic Glover, Fellow, Institute of Development Studies at the University of Sussex, Brighton, UK. Email: D.Glover "at" ids.ac.uk. The original version of this article was prepared for the workshop Playing development roles: the political ecology of performance in South Asian agricultural development at the Karl Jaspers Centre, Heidelberg University, Germany, 27-29 April 2017. I am grateful to Andrew Flachs for inviting me to participate in the workshop and to prepare this article, which I have wanted to write for a long time, and to all the workshop participants. The ideas expressed here owe a great deal to Paul Richards and other colleagues and alumni of the former Technology and Agrarian Development chair group at Wageningen University in the Netherlands, especially Sietze Vellema, Kees Jansen and Harro Maat. My ideas about farming as a performance have also been shaped by Glenn Davis Stone, particularly his work that sheds light on indigenous technical knowledge as a continuous skilling process. I would also like to thank my colleagues and collaborators at the Institute of Development Studies (IDS) and the STEPS Centre, including Adrian Ely, Adrian Smith, Amber Huff, Andrea Brock, David Ockwell, Ian Scoones, Jim Sumberg, John Thompson and Saurabh Arora, in whose company I have learned a lot about political ecology and practices. Finally, I am grateful to two anonymous peer reviewers for their insightful comments and helpful suggestions on a previous version of this article. This is the third article in Andrew Flachs (ed.). 2018. "Performing development roles: theorizing agriculture as performance", Special Section of the Journal of Political Ecology 25: 638-764.
} 
ethnographiques ou technographiques conviennent à l'étude de la performance et considère les responsabilités éthiques du chercheur lorsqu'il intervient à l'extérieur d'une performance. L'argument est présenté comme une contribution à l'écologie politique, en particulier une écologie des pratiques.

Mots clés: performance, agriculture, pratique, aptitudes, technographie

\section{Resumen}

En dos artículos citados ampliamente, el primero publicado hace más de 25 años, el antropólogo Paul Richards describió las prácticas locales de los agricultores a pequeña escala como un tipo de performance parecido a una representación musical o teatral $(1989,1993)$. Esta definición, aplicada particularmente a la agricultura a pequeña escala y de subsistencia, tiene un poderoso atractivo por razones justificadas. Este artículo examina el performance como un marco conceptual y una herramienta para estudiar la práctica de la agricultura a pequeña escala, así como el cambio tecnológico. Tomando seriamente la comparación entre el musical y la representación teatral, el artículo explora las dinámicas del performance de individuos y grupos, considera formas alternativas de concebir el "escenario" y la "audiencia", y examina la naturaleza de las habilidades y competencia de quienes realizan el performance a través de la elaboración de conceptos clave tales como práctica, ensayo, repertorio e improvisación. El artículo también discute las importantes implicaciones de un performance situado en un espacio y un tiempo particulares, configurados por su entorno, contexto ecológico y socio-cultural, y condicionado por la incertidumbre. El artículo propone que los métodos etnográficos y tecnográficos son apropiados para estudiar performance, y considera las responsabilidades éticas del investigador cuando interviene en el performance desde el exterior. El argumento está configurado como una contribución a la ecología política, especialmente a una ecología de las prácticas.

Palabras clave: performance agrícola, improvisación, tecnografía

\section{Introduction}

In 1989 an anthropologist, Paul Richards, contributed a very short chapter to an edited volume entitled Farmer first: farmer innovation and agricultural research (Chambers, Pacey et al. 1989). The book is a landmark within a body of literature in the field of agricultural and rural development, part academic and part practical and applied, that addresses indigenous agricultural knowledge and farmer-centric innovation studies. The chapter, entitled 'Agriculture ${ }^{2}$ as a performance' (Richards 1989), was based on a draft prepared for a conference and became one of Richards' most highly cited works in a long, productive and influential career. ${ }^{3}$ Not long after the book was published, Richards was invited to contribute a revised and extended version of the chapter to another book, which was published under the title 'Cultivation: knowledge or performance?' (Richards 1993). This new and slightly longer version of Richards' argument was also widely read and cited. ${ }^{4}$ The apparent reason why these two pieces became so influential is because of the resonance of a simile Richards used, in which he likened small-scale subsistence farming to a performance, akin to a musical performance. Why has this vivid analogy struck a chord for so many scholars and practitioners? In this article, I examine what it means to conceptualise small-scale farming as a performance, exploring how the analogy may be used a tool for thinking with about the activities, skills and social relations of farmers. I will show that the analogy can be used to think about the nature of performance by individuals and groups, by considering alternative ways of conceiving the 'performers', the 'stage', the 'audience', and the performance's 'reception.' I will also explore different dimensions of the performers' skills and competence, through an elaboration of key

\footnotetext{
${ }^{2}$ The title of Richards' chapter in 1989 used the term 'agriculture' rather than 'farming.' However, as the discussion in this article will make clear, Richards' argument was concerned principally with the management of crop cultivation practices on small-scale and subsistence farms, whereas the term 'agriculture' often includes diverse activities taking place off the farm (e.g. agricultural research, crop breeding, input supply, harvest processing, regulation, policy, etc.). Accordingly, in this article I have found it appropriate to discuss the performance concept as it applies to 'farming,' in most cases, rather than 'agriculture.'

${ }^{3}$ The chapter has been cited 229 times according to Google Scholar (20 Dec 2018).

${ }^{4}$ Cited 295 times according to Google Scholar (20 Dec 2018).
} 
concepts such as practice, rehearsal, repertoire, skill and improvisation. I will also discuss the implications of a performance being situated temporally (historically and within an unfolding sequence of events), spatially (in a specific biophysical place) and culturally (within a concrete institutional setting). I will link the farmingas-performance idea to the conceptual framework of technography, which is an approach to understanding technology or technical practice, also elaborated by Richards and with roots in Durkheimian anthropology and sociology. Finally, I will discuss the extent and limits of the metaphor's practical utility as a guide to research methodology.

\section{Farming as a performance: the originality of the idea}

Richards' 1989 chapter opens with an observation based on his own fieldwork in a Mende village of Sierra Leone, where he noticed that the activities and skills required of a farmer wanting to organise an agricultural working party were similar, in several non-trivial ways, to those involved in organising a village dance. Richards also observed a substantial increase in productivity when a working party was entertained by drumming, compared with the same group when they worked without music. The difference was as large as might be hoped for by following the technical practices of cultivation that were recommended by agricultural extension officers. Richards' observations showed that performance mattered materially to the outcome of farming activities; however, he also noted, the 'performance factor' was largely ignored by agronomic researchers. The problem, according to Richards, was that farming systems researchers were biased in their interpretations of how small-scale cultivators farmed. He used as an example an account by Michael Watts of Hausa farmers' strategies for coping with unpredictable rainfall in northern Nigeria. Their farming practice involved:

.... a series of rolling adjustments to drought. If the rains are late or stop unexpectedly, the first planting of sorghum may fail. The existing farm is replanted as many times as is necessary or until the farmer no longer has any seed left. At each replanting a different seed mix may be tried, better to fit available resources to changing circumstances. As the need arises and resources permit the farmer may then hedge or criss-cross the main plot with various back-up and insurance crops. (Richards 1989: 40)

Scientists were inclined to interpret the cropping patterns they observed in farmers' fields as results arising from the implementation of a systematic design conceived in advance. According to Richards, "This is to misunderstand almost entirely what has happened" (Richards 1989: 40). He continued:

The crop mix - the layout of different crops in the field - is not a design but a result, a completed performance. What transpired in that performance and why can only be interpreted by reconstructing the sequence of events in time. Each mixture is an historical record of what happened to a specific farmer on a specific piece of land in a specific year, not an attempt to implement a general theory of inter-species ecological complementarity (as plant ecologists might suppose).

Researchers, then, are looking at the wrong problem. They are looking for the combinatorial logic in intercropping where what matters to the Hausa farmer is sequential adjustment to unpredictable conditions. It is important therefore not to confuse spatial with temporal logic not to conflate plan and performance. (Richards 1989: 40)

Richards saw that scientists' misunderstanding of what they saw in farmers' fields was a symptom of a larger problem in the relationship between formal science and farming practice. 'Controlled' field trials and formal experiments were designed to test only the effects of technical factors, eliminating or minimising (i.e. bringing under control) all 'interferences' from temporal and even spatial factors, let alone cultural and social components of the farming system, which in reality helped it to function. Agronomic experiments 
misrepresented what was actually at stake for real farmers, who could not avoid grappling with the complexity of crop cultivation amid the urgency, vitality and uncertainty of real-world conditions. As Richards observed, "the issues at stake in performance only become apparent when the performance is for real" (Richards 1989: 40).

The problem was not only that the experiments were artificial; they failed to take account of the fact that small-scale, subsistence farming is only one productive activity within a wider economic livelihood. While agronomic experiments might investigate interactions between genes and environments $(\mathrm{G} \times \mathrm{E})$, they typically ignored interactions with cultural mechanisms that could make the difference between a successful and an unsuccessful harvest (Richards 1993). Richards explained that crop cultivation and livestock husbandry were deeply embedded in social relations and cultural institutions, which not only enabled farming to take place but also gave these activities their purpose and meaning. Farming served social purposes that included, but transcended, mere physical and economic survival. While agronomists and agricultural economists sought to evaluate technical practices in terms of yields or productivity, farmers themselves would "judge the success of their on-farm actions by whether they further their social projects more generally" (Richards 1993: 72).

Particularly in the 1993 revised version of his chapter, Richards questioned the reification by scholars of subsistence farmers' technical practices as if they represented a discrete system of "indigenous agricultural knowledge", which was often denigrated by scientists at the same time as it was celebrated, with equal naivety, by "anthropological romantics" (Richards 1993: 61). Richards proposed that what was generally called "indigenous knowledge" was better understood as "the product of a set of improvisational capacities called forth by the needs of the moment" (Richards 1993: 62). He insisted that what mattered was not building an abstract model of farmers' knowledge systems, but understanding how farmers got started and managed to "keep going" in spite of difficulties, and (if successful) "do well." He compared this practical skill to an experienced musician's ability to squeeze out a decent performance even when events 'on the night' were not going smoothly (Richards 1989, 1993). Richards' approach brought the skilful practice of performers into the centre of attention. He suggested that the concepts referred to as "local knowledge" and "(so-called) indigenous technical knowledge" could be captured better by the term "performance knowledge" (1993: 66).

Richards proposed that agricultural science occupied a relationship to farming that was somewhat like that of music critics and scholars in relation to concert performers (particularly in 'Western' musical traditions). A music critic or agricultural scientist might possess expert knowledge of an abstract kind, but very often they lacked the practical experience and personal commitment to be able to perform at the same level as the practitioners whose work they judged. They risked little, compared to the people actually engaged in the performance. Outsiders might critique the farmers' performances and offer their suggestions for improvement, but they were not the ones who had 'skin in the game.' They were not necessarily even competent to judge the success of the performance, since they might not be the ones defining the criteria of a successful outcome.

The originality of this anthropological argument carried important implications for the organisation and delivery of technical interventions that were designed to improve small-scale agriculture. Since farming was a socially and culturally embedded performance, Richards argued, it was "not corrigible by outsiders" (Richards 1993: 72). It followed that conventional approaches towards agricultural and rural development projects, which typically used to involve inflexible technical prescriptions designed by outsiders, that were designed to be implemented in a top-down manner, could only meet with limited success.

Richards' pair of short chapters had posed an important challenge to the perspectives and practices of development professionals and scholars, which continues to resonate today. It is my experience that researchers and students in fields linked to development studies, such as political ecology and rural sociology, find Paul Richards' framing of small-scale farming as a type of performance intuitively appealing and intellectually stimulating, yet the richness of the idea, including its theoretical value and methodological utility, is often unconsidered or underestimated. Therefore, this article has a simple goal: to describe and discuss how the likening of small-scale farming to a musical performance opens up fruitful ways of thinking about, understanding, and investigating farmers' practices, skills and knowledge.

Farming-as-performance is a valuable idea for political ecologists, contributing to the ecology of practices, that is, the study of practices within their environments (Stengers 2005). The approach represents a 
handy conceptual tool and a useful methodological key to the study of relations between farmers and their communities, their tools and their agro-ecologies, through the empirical and analytical lens of practice (Shove, Pantzar et al. 2012; Arora and Glover 2017). It facilitates the discovery and exploration of relations and interactions among people, places and things, which constitute small-scale agriculture in specific times and contexts. It helps to uncover the social relations, economic exchanges, cultural symbols, material interactions and biophysical relationships that shape small-scale farming practice and create meaning and purpose for the people involved in it.

As soon as the idea of performance is mentioned, Erving Goffman's dramaturgical approach to sociological analysis seems to be a natural touchstone (Goffman 1959). Goffman used theatrical metaphors and analogies to explore 'the presentation of self in everyday life', strongly emphasising the sociological functions of performance as well as the psychological aspects of impression management, undertaken by individuals involved in social and professional interactions, who were also able to retreat into a 'backstage' space where they could rehearse, prepare, seek support from their peers, or simply to let their hair down. Goffman's ideas about the front- and backstage arenas are indeed helpful, but in this article I want to follow Paul Richards' lead and concentrate on the usefulness of a performance lens for examining the technical practices and practical skills of farmers, while a performance is ongoing, where the stakes are real, and the premium on achieving a successful outcome is high.

In the rest of this article, my aim is simply to illustrate and discuss a number of dimensions of the notion of farming-as-a-performance. Specifically, I will explore briefly a number of ways in which development scholars and professionals have found, and may find, it helpful to consider:

- the performers: who they are and what they do, individually and in groups;

- the stage and venue where the performance takes place, both as real biophysical spaces and as an arena with specific cultural and relational attributes;

- the audience: who and what they are, and how they relate to the performance;

- the performance itself as an unfolding social occasion, situated in time;

- scripts, roles and their interpretation;

- and improvisational skill.

In the discussion that follows, I invite the reader to distinguish between four aspects of performance:

(1) performance as the practice of craft skills and improvisation, unfolding in time and place;

(2) performance as a presentation to and for the benefit of a particular audience, accounting also for the role of intermediaries such as critics, interpreters and summarizers;

(3) a performance as an occasion or an episode, situated in time, which might be convened and orchestrated by an impresario, conductor or master of ceremonies,

(4) performance as a measure or index of the outcome or results of an activity or intervention, in other words, performance in the economist's or investor's sense, to be assessed and measured, and evaluated as a success or failure.

In this last aspect, we can consider also the experimenter's perspective - that of the organiser and implementer of agronomic field trials.

I will also suggest that an ethnographic approach, specifically technography, can be a useful and appropriate conceptual and methodological framework for carrying out research into farming as a performance situated in space and time. In the final section of the article, I will summarize the key points and draw some conclusions for the responsible and ethical practice of researchers. 


\section{The performer(s)}

The first and most obvious performer who jumps out of Richards' discussion is the farmer $(1989,1993)$. It is relatively easy to understand this individual as a performer, like a musician or an actor. He or she appears at first sight to be the principal decision-maker, who determines what to plant, when to plant and how to plant it, how to care for the crop in the field, how to expend and conserve his or her resources, when to harvest, and so on. However, as Richards shows with his examples, the farmer is not free to create the performance with a free hand. In particular, he or she must interact productively with others. For any farm operation that is beyond the capacity of one individual, the farmer must collaborate with other people, inside and outside his or her own household. This is true not only for practical and economic reasons, but because small-scale farming is a socially embedded activity that takes place within cultural and institutional frameworks such as market relations, social hierarchies, religious practices and behavioural norms.

Farming is also ecologically and geographically embedded, so the farmer is additionally constrained to cooperate with a wide variety of nonhumans, including living organisms such as crops, livestock, weeds, soil microbes, pollinators, viruses and pests, material entities such as hand tools, engines and pumps, irrigation canals, roads and granaries, as well as complex bio-geo-physical phenomena such as weather, climate, seasons, soils and topography (Arora and Glover 2017; Callon 1986; Callon 1987; Latour 2005). It follows from this that the farmer is not fully in control of their farming operations. The farmer must undertake their performance within a complex and dynamic social - ecological system characterised by contingency and uncertainty, in which risk is an intrinsic feature.

Paul Richards' originality was to propose that, to be successful in this context, an individual farmer needed to exercise skills that resembled those used by a musician performing on a stage for an audience. As an individual, the farmer needs to use techniques that may be learned through observation, practice and experience. As time goes by, a farmer builds up a repertoire of techniques, methods and practices that he or she can draw upon to suit the occasion. The successful farmer needs to develop a sensitivity to the unfolding progression of farming operations and the vagaries of the weather during the agricultural season, so that he or she can monitor progress towards a successful harvest, detect emerging threats and opportunities, and be ready to make timely adjustments if things appear to be going wrong. The farmer must also draw on psychological resources to engage in the performance and keep going despite difficulties.

Understanding the farmer as an individual performer is a useful step, but many tasks on the farm are carried out by groups or teams rather than individuals. Across a range of spatial and temporal scales, people work together to accomplish tasks in the field, on the farm or within an agricultural landscape. The individual farmer operates with an ensemble of family- and household-members, hired laborers, and a community of neighbors. Individuals within households are commonly given responsibility for different tasks and domains of domestic and agricultural work. At the level of a specific task, the relevant performance might be that of an individual worker, such as a hired laborer, rather than the head of the household. The household, through the persons of its individual members, may cooperate with members of other households to perform collective tasks, such as planting or harvesting, to procure services such as plowing, or to coordinate the management of shared resources, such as irrigation infrastructure or common property. To cooperate in this way, effectively and productively, the individual performers must attend to each other, adjust the tempo of their work, fall into a rhythm with one another, and find other congenial and sympathetic ways to cooperate harmoniously.

One can observe this happening in real time during an operation such as the transplanting of rice seedlings by a group of women (Maat 2018), or by watching a working party accompanied by music, such as the one described by Richards $(1989,1993)$. It is less easy to observe when it comes to forms of cooperation and mutual accommodation that operate across larger scales and longer timeframes, such as a farming season, an annual cycle, or a decade, or the scales of a watershed or valley. It takes an imaginative leap to realise that farmers who synchronise their planting dates across a landscape are falling into rhythm, not only with their human neighbors, because they need to cooperate with them on tasks such as plowing and sowing, but also with pests that could cause more harm if farmers fall out of step with the crowd (Htwe, Singleton et al. 2012). Historically, it was not easy for observers to understand how water temples and seasonal rituals played a key 
role in allowing an entire community of farmers to regulate the supply and distribution of irrigation water over a long term (Lansing 1987).

The performers must also try to maintain good relations with one another, not only during the performance but also 'offstage', before and after the task is performed, in between growing seasons, and in social interactions and ritual events (see Maat 2018). If interpersonal relations between individuals or households are tense or difficult, these frictions might need to be overcome or put to one side, in order to allow a successful farming performance to be undertaken 'onstage.'

The analogy between farming and musical performance is also helpful for understanding that individual performers and ensembles are exercising techniques and carrying out technical operations that are part of a cultural repertoire. The individual practitioner may have a characteristic style, and might perhaps be recognised individually as a novice, a virtuoso, a specialist, an innovator or an incompetent, but these distinctions will be applied by, and with reference to the standards and expectations of, a community of practice (Wenger 2000). As Marcel Mauss observed when discussing habitus, the cultural and technical repertoire is held and, in a general sense, enacted or performed by an entire community or a socio-cultural group (Schlanger 2006). Just as communities have their distinctive instruments, styles and genres of music and dance, two communities might approach a similar technical practice, such as digging trenches or growing crops, in culturally distinct ways, using culturally specific tools, techniques, and forms of organisation (Schlanger 2006; Sigaut 1996, 2002). The techniques and styles of performance are passed on by each cohort or generation to the next, while the repertoire of practices continues to evolve and change through exposure to new insights and sources of inspiration, through the creative agency of individuals and groups, and through adaptations to accommodate changes in the surrounding context (Arora and Glover 2017; Schlanger 2006).

Given that the farmer him- or herself may not be the individual who performs every discrete task on the farm, the performance lens helps us to understand the farmer's role as something like a director or supervisor of his or her household's farming performance as a whole. The worlds of music and theatre offer a number of characters through which we can understand this type of role, such as producer, promoter, impresario, conductor, show runner or stage manager. These were the kinds of roles invoked by Richards $(1989,1993)$ and others (e.g. Netting, Stone et al. 1989) when they described the social skills and hospitable resources needed by a farmer in order to convene a working party to carry out a task on their farm. In the example described by Richards, successful farming required the farmer to provide a range of acceptable rewards and incentives that would bring the laborers to the field and motivate them to work well. These appurtenances included food, drink and music. The refreshments have a similar function to the bars and restaurants in a commercial entertainment venue, which help to attract an audience so that the performance can take place (Richards, pers comm.). In this sense, the farmer can be understood as the show's host, who provides and dresses the venue where the performance will be given.

The analogy can be taken further if we perceive that the farmer's overarching task is to orchestrate a performance that involves nonhumans, such as plants, soils, earthworms and fertilisers, as well as the humans who make up his or her labor force (see Münster 2018). In the language of Actor Network Theory (ANT), the farmer creates a stage or venue where a diverse cast of human actors and nonhuman 'actants' may be 'enrolled' and 'interested' in achieving the farmer's goals (Callon 1986). In case this seems an esoteric claim, it is a true reflection of some agricultural scientists' discourse. For example, advocates of an agro-ecological rice cultivation method called the System of Rice Intensification (SRI) have suggested that the farmer's humble job is to make the rice field a congenial place where rice plants can express their genetic potential (de Laulanié 1992; Stoop, Uphoff et al. 2002; Uphoff 2002; and see Glover 2011, 2014). Henri de Laulanié, the man credited with discovering or inventing SRI, urged farmers to care for their rice plants in the same way servants or disciples would their masters (de Laulanié 1992: 17). Taking his lead from de Laulanié, Norman Uphoff has suggested that if farmers want to unleash the true yield potential of rice, they should learn to work in harmony with rice plants rather than try to control or drive their development and growth (Uphoff 2002). In SRI discourse, the vigorous growth of rice plants when treated to the benefits of SRI management has often been depicted as a spectacular performance that convinces sceptical farmers to adopt the new methods (Glover 2011). This 'seeing is believing' logic continues to be invoked by SRI promoters today, as they set the stage on 
which an unpromising inauguration of the rice season should produce a striking display of vigorously flourishing rice plants a few weeks later.

In a very similar way, the advocates of 'conventional' modern agricultural intensification also argue that the farmers' job is to supply the inputs that will allow thirsty and fertiliser-dependent modern crop varieties and hybrids to achieve their potential. The phenomenon of the 'yield gap' is a socially constructed index that measures the size of farmers' failures to facilitate or orchestrate the performance of which modern crops and farming technologies are believed to be capable. At the extremes, the principal artists of the farming performance are sometimes portrayed as the genes and molecules within crops and livestock, rather than whole plants, animals or people (Glover 2014). From an ANT perspective, all of these and other actors and actants are engaged in a collective performance, and it can be illuminating to see the farmer's critical role as something like that of a ring master, stage director or choreographer, who brings together the performers, arranges the stage, and seeks to lead and direct a successful performance.

Although I have concentrated here on the impresario role of farmers, this type of role might also be played by off-farm actors, such as a contract farming (outgrower) company, a social enterprise, a farm cooperative, an extension agency, a development project or programme, or agronomists carrying out field trials on the farmers' land. In such cases, the stage is often set according to a design and a script provided by the offfarm actors, who may also provide incentives for the farmers to engage in the performance. This type of situation is likely to arise as soon as small-scale producers engage in commercial production, when they are connected to value chains that are typically governed by more powerful actors, such as a large company or the major stakeholders of a standard-setting body like the Fairtrade Labelling Organisation (Bacon 2010; Bush 2018). Off-farm actors may be the 'didacts' identified by Stone, who seek in one way or another to 'tell farmers how to farm' (Stone 2016: 6). Their involvement is potentially problematic - for social justice and inequality, agro-ecological sustainability, the distribution of financial benefits and risks, etc. - if their interests diverge substantially from farmers' interests, or if they lack important knowledge about local biophysical conditions, cultural institutions and social practices. If the principal performers on the farm adjust their practices instrumentally in order to meet the expectations of off-farm actors, questions might also be raised about the potential effects on the quality and originality of the performance, its suitability for local conditions, the creativity, skills and resilience capacity of the performers, and the vitality of their cultural repertoires. On the other hand, didacts are a key audience, whose expectations must be met if the performance is to be judged a success; I shall return to this point below.

\section{The stage or venue}

How can the idea of farming as a performance be useful for thinking about the venue or stage where farming takes place? Most obviously, the farm is a real biophysical space, an agro-ecological setting. There is also a question of scale: the stage might be the plot, the field, the farm or the command area of an irrigation system. With any of these as the stage, the performer in focus could be a farmer or laborer, a bullock pair, a crop plant, an insecticide or a pheromone trap. This is the broad domain of agronomy, and it implies a focus on the performance of technical operations such as plowing, planting, weeding, and harvesting, the rotation of crops, and the spraying of pesticides. The performer in focus for these tasks might be a human, such as the farmer or a laborer, and the observer might be an ethnographer, ergonomist or extension officer. Alternatively, the performer of interest might be a crop variety, in which case we are in the realm of the field agronomist or plant breeder, and our interest is in performances at the scale of a plot or field, such as germinating, growing, flowering, setting seed, and the competitiveness of plants for light, water and nutrients. Or, the performer concerned might be a tool or machine, and we are alongside the agricultural engineer, observing the sharpness and temper of the plow blade as it cuts and turns the soil, or measuring the quantity of water moved in one minute by a single electric pump.

The performance lens encourages us to think, as an agronomist or ecologist should, about the biophysical characteristics of the agricultural stage, and how they influence or limit the farming performance. The venues for musical and theatrical performance have individual characteristics, which affect the kinds of performance that can be undertaken there. There is a big difference between a stadium arena, an eighteenth- 
century concert hall and the intimate back room of a pub. To deliver a successful performance in these different spaces, musicians and actors must adjust their practices to suit the size of the stage, the acoustics of the venue, the proximity to the audience, sight lines from the back of the house, and so on. Translated to agriculture, relevant characteristics would include features such as the local topography, soil quality, and seasonal variations in rainfall, sunshine and temperature. These features will define the limits of what kinds of crops can be successfully cultivated in that location, and strongly influence the methods and practices that are used in farming.

Many farmers are fortunate not to face the challenge of adjusting each performance to a different venue, however, just as a touring musician or a travelling player must adapt to each new setting as quickly and adeptly as possible, a landless laborer, short-term tenant or sharecropper, swidden farmer, migrant, refugee or internally displaced person, or a newlywed relocating to live with his or her spouse's family, will at times face the task of adapting quickly to a new place. A similar challenge faces rural people who are trying to recreate a viable farming practice in the aftermath of a natural disaster or civil conflict. Like a musician who adds a rider to their touring contract, or the new owner of a music venue, the farmer strives to alter the characteristics of the new setting in order to make them more familiar, comfortable, and congenial to a good performance. They may try to conserve and bring with them as many familiar and reliable seeds and implements as they can carry (Richards 2006, 2015; Richards and Ruivenkamp 1997). They may try to improve the land through investments in fences, soil quality, drainage channels, storage ponds, terraces, and so-on (Batterbury 1996). Beyond certain practical and economic limits, however, the performance venue may not be amenable to alteration; the farmer or laborer must still adapt his or her performance to suit the new location, and be ready to adjust their evolving plans in response to events. I shall return to this balance between planning and performing below.

Agricultural performances also take place on other kinds of stages, such as markets. These may have the attributes of real places, such as a gathering of vegetable sellers, or the intangible qualities of advertising and branding, commodity trading, and food safety regulations. As noted above, the characteristics of agricultural markets may have decisive effects on commercially oriented farming performance, just as the attributes of a market for entertainment have on commercial music and theatre. To understand how this influence works, it is particularly helpful to assume the perspective of an impresario or concert promoter, who tries to discern which kinds of products are in demand, whether gaps exist in the market, and what their competitors are offering. They try to shape markets through advertising, and to occupy niches where they can cultivate a consumer base. For example, in contemporary agricultural marketing, blogs, vlogs, agri-tourism, farmers' markets, farm open days and social media are stages for the performance of 'alternative' farming and its products, such as organic vegetables, grass-fed beef, and permaculture (Stone 2018). These kinds of platforms serve to make intangible or invisible aspects of the production process that lie behind some agricultural products evident to consumers who value them (Glover and Stone 2018; Stone 2018).

\section{The audience}

If farming is a performance, who or what constitutes the audience? An audience's role is to judge the quality of the entertainment and show its appreciation for a good performance. Skilful performers can earn rewards in the form of applause and recognition, as well as the ability to earn a living. The audiences for a farming performance have several guises, some of which are less obvious than others. One type of audience might be glossed, crudely, as 'Nature.' If the farmer's performance is skilful and her crops and livestock find it congenial, they should thrive, yield well and produce a good harvest. The reward will be food for the household, a full granary, and perhaps a surplus that can be sold for profit in the market. A poor performance might be punished with crop failure, low yields, and avoidable losses to pests and diseases.

Another type of audience is made up of household members who eat the produce, or paying customers who purchase it in the market. These consumers may show their appreciation for the produce by praising its variety and quality, or by choosing it over alternative products or rivals' produce. If the farmer offers a lowquality or unhealthy product, charges too much, or brings items to the market that are not in demand, the performance may be met with low sales and wasted crops. An audience might show no appetite for the product, despite its quality and affordability, due to a change in fashion and taste, or even because the product has been 
tainted by an unfair association with unsafe or low-quality products that have been brought to the market by a rival producer.

Another audience type overlaps with the category of performers, because it includes other members of the same household or community, who are also performers in their own capacity and represent a peer group. These members of a shared community of practice are not only the people best qualified to judge performer's skill and diligence, they are also the people whose judgement really counts, and whose opinion is valued, when it comes to rating a performance against the expected standards of a cultural repertoire. Just as other musicians or actors may be the best qualified judges of a musical or theatrical performance, so a farmer's family, neighbors, friends and other community members may be his or her keenest arbiters, sternest critics or most loyal fans. They might also be his or her fiercest rivals. The rewards of a warm review from other members of this community of practice may be particularly sweet, and may be observable in the deference and respect shown to an esteemed farmer, or the way community members seek his or her advice. On the other hand, a poor performance might lead to ridicule, as well as a difficulty in finding work as an agricultural laborer.

A performer is also his or her own audience, and may achieve the satisfaction and self-respect that come from providing for oneself and one's family, practising a difficult skill, or overcoming obstacles to complete a difficult task. Alternatively, an inability to put food on the table, and even an unpreventable crop failure, could be very damaging to a farmer's self-esteem, leading in tragic cases to desperate acts, such as self-harm and suicide (Vasavi 2012).

Another kind of audience for agricultural performance is the broad category of critics, as noted by Richards and discussed above (1989, 1993). The critics might include agricultural extension workers, policy makers, rural sociologists, irrigation engineers, certification agents, and others. The critical insights and suggestions for improvement made by these groups might be found helpful by some performers, on some occasions, but are often seen as irrelevant or useless (Richards 1989, 1993). On the other hand, as Glenn Stone argues, some kinds of agricultural performance are expressly designed as 'spectacles' for the benefit of a particular audience of critics, such as extension officials, programme funders and product buyers (2018). In such cases, farming's traditional function as a productive, material livelihood activity might even take second place to its primary role as a spectacle designed to earn rewards from a particular audience. For example, a 'show farmer' might go through the motions of performing a prescribed set of technical practices, such as organic cultivation, integrated pest management or row planting, simply to obtain rewards such as an elevated social status, contracts, subsidies or grants (Flachs 2018; Stone 2018). Farmers might be maintaining a 'front stage' performance for the benefit of programme staff or product buyers, while they continue to practise their former cultivation methods behind the officers' backs (Goffman 1959).

An elaborate kind of stage management is involved in the configuration and conduct of agronomic experiments ('field trials') and demonstrations (Shepherd and McWilliam 2011, Maat and Glover 2012). In the former case, the scientist, performing as a kind of master of ceremonies, is also the primary audience for the performance, where the ostensible goal is to bring together a cast of actors and actants under controlled conditions, in order to measure and evaluate how they interact and perform together. The purpose of controlling the conditions under which the performance takes place is to eliminate the human and social element, and make the farm field more 'laboratory-like' (Henke 2000). As Richards pointed out, this makes performances artificial in ways that make them a poor guide to the real predicaments that face small-scale farmers in resourceconstrained environments $(1989,1993)$. Field trials are also an interesting case where the scientist is organising the players and the venue, but not dictating the script. Her purpose is to see how the players perform and the result they produce.

Demonstration plots are organised and managed in similar ways to experiments, but the desired or intended outcome has been conceived in advance, and the goal is to display the performance to an audience of farmers, in order to persuade them to adopt the practices or materials being demonstrated. In this case, the surrounding conditions are controlled as strongly as they are for experiments, but for a different purpose. The objective is to ensure that the assembled actors and actants will perform as expected. For this purpose, a tightly controlled script or score is used, which determines a schedule of inputs and a timetable of activities to be implemented under the close supervision of a technician, whose job is to monitor the performance and intervene 
when necessary, to ensure that it does not deviate too far from the intended track. This is a type of spectacle designed to convince an invited audience of farmers, who are supposed to derive particular lessons from the performance. In case the spectacle is unclear or the lesson is ambiguous, the performances will be mediated by salespeople and extensionists, whose job is to interpret and explain the demonstration and ensure that its messages are understood by the target audience (Stone 2018). We might think of these mediators and interpreters as analogies to the chorus of classical Greek theatre, or the narrator of a documentary film. In the context of agricultural development, Stone calls these people and their organisations 'didacts', who represent off-farm interests that aim to influence farmers' practices (Stone 2016).

\section{A performance situated in time and space}

As well as existing within a cultural frame, a performance is also situated temporally and spatially. Temporally, the farming performance is situated in two distinct senses: on one hand, the performance is historically located. It emerges from a specific local history of farming techniques, social relations, cultural institutions and rituals, meteorology, economics, and so on. The performance is informed and shaped by previous experiences, existing cultural and technical traditions, established associations, and prior investments in infrastructure and equipment. On the other hand, the farming performance is a sequence of activities within a flow of events, which unfolds in real time. Each performance is a unique enactment, which bears a familial resemblance to similar performances during other seasons. Each performance is subject to the vagaries of weather, fluctuating prices, illnesses, injuries, births and deaths, natural disasters, and other hard-to-predict events, trends, shocks and stresses. As with any performance, these conditions make the farming performance intrinsically contingent, and its outcome uncertain.

Uncertainty and contingency demand the exercise of coping skills, such as monitoring the environment and improvising in response to opportunities and threats. Resilience depends on the ability to cope with new situations. To be really good at coping, small-scale farming households need to acquire competence in a wide range of farming systems and operations, at different scales and over various time periods (such as cropping seasons and annual cycles), be familiar with a range of crops, seeds, pests, techniques, tools and materials, and understand how the farming system as a whole is integrated. Successful coping often relies also on the maintenance of social relationships, and on psychological rituals that sustain the individual's and community's confidence to keep going (Richards 1989, 1993, 2004). Arguably, this makes the skilful and experienced head of a small-scale farming household rather like the 'reliability professional' or 'high reliability pastoralist', who has the competence to produce highly reliable outcomes from complex and dynamic systems, where formal management protocols and procedures may often prove to be inadequate to manage risks or prevent breakdowns ( Roe 2013, Roe, Huntsinger et al. 1998).

Roe and colleagues' analysis of reliability practice among pastoralists demonstrates that skilful improvisation is not random activity in response to unexpected events, but a structured, purposeful, adaptive behaviour in situations where complexity and variation are expected features of the system (1998). Improvisation is shaped by practices of attentiveness and information gathering, which are used to monitor the functioning of the system and its surrounding environment. Action in this context is guided by past experiences, cultural conventions, and rules of thumb that assist with efficient and timely decision making. Since there is a high premium on a reliable outcome and a high cost to failure, reliability institutions impose limits on learning through trial-and-error from random experiments (Roe, Huntsinger et al. 1998). Instead, an improvisation is created from a repertoire or portfolio of well-practised elements, such as rhythms, melodies, scales and riffs in music. The ability to organise these building blocks into a successful performance is not evenly distributed or easily acquired. Not everybody will be equally skilful in improvisation. It takes experience and practice, good anticipation and effective preparation, as well as self-confidence. A skilful improviser is an experienced performer who has attained a high level of mastery over a repertoire of practical skills and technical knowledge, which enables him or her to combine elements from the repertoire in original ways, and innovate to create a unique performance for a new situation. The success of the performance might also require a measure of good luck as well as a sympathetic, cooperative audience. 
The situational skills involved in performance and improvisation are hard to express in words. They are typically bodily and emotional rather than intellectual. They are often acquired primarily through experiential and practical learning and through repetition, rather than intellectual or textual study. Along with learning to play a musical instrument, other good examples are learning to ride a bicycle (Jansen and Vellema 2011) or learning how to tighten a nut with the right amount of force (Dant 2010). An essential part of Richards' proposition in his pair of farming performance chapters was that so-called 'indigenous technical knowledge' was wrongly conceived if it was understood as a sort of stock of formally codified information, like a library or database, from which members of a community could retrieve farming blueprints or solutions to their farming problems $(1989,1993)$. Instead, small-scale farmers' knowledge ought to be conceived as uncodified, situational, tacit, embodied practice or habitus (Schlanger 2006).

A consequence of this insight is that an agricultural 'script' (such as the instructions printed on a seed packet, or the training delivered by an extension officer) provides only a part of the resources necessary for a successful performance to be undertaken, and it is not necessarily an essential part. A script creates a kind of dialogue between the composer or playwright and the performers of the music or play. The interaction is similar to the one created between a designer of technical artefacts and systems and the practitioners of technology (Arora and Glover 2017; Glover, Venot et al. 2017). Each performance of a musical score or a play involves a unique interpretation by the performer or group of players. Music and theatre critics endlessly compare performances and performers, appraising their respective styles and critiquing their interpretations of movements, phrases, scenes and roles. Annapurna Mamidipudi has used the examples of contemporary performers of Karnatik classical music and practitioners of traditional Indian handloom weaving to show how improvisation and innovation are central to the skillsets of these craftspeople, even though they are performing within traditional genres (Mamidipudi 2016). Even when a script is involved, some elements of creativity and improvisation are also essential aspects of the performance. In agriculture, technical artefacts and the prescriptions of agronomists are like scripts, which need to be freshly interpreted by farmers if they are to be successfully accommodated in a new setting (Glover, Venot et al. 2017).

Traditional or conventional farming practices can also be understood as cultural scripts. Culture has been defined as 'an adaptive process that accumulates partial solutions to frequently encountered problems' (Hutchins 1995: 354). Because the solutions are partial, the creativity and improvisational skills of practitioners are crucial to successful performances (Arora and Glover 2017). While cultural traditions and recipes strongly influence practice, they do not determine the myriad actual performances by particular performers at specific times and places. When a conflict arises between a traditional agricultural institution and a novel farming technique, both of which are kinds of scripts, the community members may find creative ways to reinterpret the tradition and adjust the novel practice, so that they can both be accommodated (Sen, Maat et al. 2017). This allows skilful practitioners to navigate deftly between the expectation of conformity with a traditional repertoire and the need to adapt flexibly to meet new economic challenges and satisfy changing tastes (Mamidipudi 2016).

A critical perspective on Richards' ideas about performance $(1989,1993)$ holds that he placed too much emphasis on skills such as improvisation, 'inventiveness', 'opportunism' and 'problem-solving' (Batterbury 1996). The geographer and political ecologist, Simon Batterbury (1996), objected that Richards had portrayed farmers as 'hitching a ride' on natural processes, rather than striving to bring them under control. While this view might be valid for the areas of Sierra Leone where Richards had worked, in less-favoured agro-ecologies, more assertive agricultural management styles would be necessary. In semi-arid areas like the Sahel of Burkina Faso, farmers might have to 'build' their farms from the ground up, for example creating fertile planting pits by digging holes and bringing manure or mineral fertilisers to put into them. According to Batterbury, these farmers needed to follow a long-term strategy, and could not merely respond to short-term opportunities and threats. Without a plan, the prospects of a successful farming performance were quite bleak. My own view is that the performance concept is large enough to accommodate both Batterbury and Richards. Though a plan is not quite the same thing as a script, it plays a very similar role, as a structuring narrative that motivates action and guides the performance. A plan might resemble a detailed blueprint, where the scope for improvisation is constrained, but it could also be a loose set of general principles for action, where improvisation is expected to fill in the details. A farmer may make general plans to reach a long-term goal, but he or she must still be ready 
to adapt the performance in response to events, which provide opportunities to move towards the goal or threaten to disrupt the plan. A plan or script, and adaptive, improvisational practice, are both involved in creating a successful performance (Suchman 1987).

\section{Implications for political ecology and research}

The performance lens focuses our respectful attention on the agency, skills and practices of the actors on the stage, as well as the activity behind the stage, which allows the performance to take place. It encourages us to adopt a relational, interactional and situational perspective on the practices of the human and nonhuman actors involved in the performance, including farmers and their various audiences, as well as critics, impresarios and others. The performance lens can help researchers to contribute to the political ecology of practices, including the ethical injunctions to care for the knowledge, values and perspectives of the people engaged in practices, for whom they matter and have meaning, and who we claim to be trying to help (Arora 2017; Stengers 2005). Conceptually and methodologically, it proposes the observation and analysis of human activity within its biophysical environment, its social relations, and its political, cultural and economic settings. The performance lens can be particularly useful as a way to highlight the performance and distribution of unequal power relations and agency through practice (Arora and Glover 2017).

Even if we were to adopt a top-down, programmatic perspective on agricultural research and development interventions, we could still learn from the performance concept and make an argument about improving the 'efficiency' and 'effectiveness' of development programmes: If one's goal is to improve farmers' outcomes, close 'yield gaps' or increase farm productivity, then it is better to understand the practices and perspectives of the people and communities of practice directly concerned, especially the ways farmers adapt their performances in response to the new opportunities presented by technology (Glover, Venot et al. 2017).

Paul Richards' assertion, at once an ethical injunction and a practical contribution to political ecology, is that it would be inappropriate to adopt such an instrumental perspective on farmers' performances, which ought to be valued in their own right (Richards 1985, 1986). External actors can help to shape the conditions for a successful performance, and they can offer assistance to the performers, but the performance is only for the performers themselves to deliver. Abundant evidence shows that small-scale agriculturists are often capable of constructing remarkable performances using scant resources. Arguably, instead of promoting new technical packages, the most supportive thing outsiders should do - when asked - is to allow space and offer additional resources (including technical artefacts and scientific knowledge) from which farmers might construct new performances that they find meaningful and valuable. Aside from that, scientists should try to understand the cultural 'auspices' under which the performance occurs, otherwise there is great potential for miscommunication. Practices and rituals that make no sense to an external observer might be crucial to the ability of individuals and the community to perform, and keep going in the face of difficulties. Richards reminds us that what matters to the performance is not the scientific respectability of the ritual, psychological and social techniques used, but, do they work (Richards 1993)?

A potential criticism of the performance lens, anticipated by Richards in his work on farmers' indigenous technical skill, is that it implies a naïve, sentimental celebration of farmers' traditional 'wisdom' (Richards 1985). This is not a necessary implication. It should be recognised that a good outcome in a complex situation is a skilful accomplishment, but performance skill is not evenly distributed. An individual might be inexperienced, unprepared or inept. A cultural repertoire of traditional practices might not hold the best responses to a given situation. Choices and decisions that are made in a complex, dynamic and uncertain environment, with scant resources, incomplete information and high risks, might make sense in the moment, but could lead to negative effects over a larger scale or longer term - consequences that could be invisible to or unrecognised by the performer at the time. What matters more than the usefulness of the community's 'stock' of traditional knowledge is whether the environment in which they are making decisions is conducive for an accurate assessment of risks and payoffs, and whether cycles of learning and knowledge exchange, or 'skilling', are healthy or dysfunctional (Stone 2007).

In this connection, Richards' insights into the significance of performers' coping strategies and improvisational skills might contribute helpfully to ongoing debates about resilience in social-ecological 
systems. Although analysts of resilience acknowledge that learning and adaptation are definitive features, resilience itself is typically approached as a cumulative, systemic property rather than something accomplished (if at all) through myriad performances by individuals and groups as they try to cope with - that is, make robust decisions in the face of - change and uncertainty. This focus on macro-level 'performance measures' rather than micro-level 'performances' is justified partly by the recognition that local actions that make sense to individuals may not produce sustainability at a system level (Anderies, Folke et al. 2013). Here, Richards' understanding of coping as a normal feature of performance, which involves individual improvisation and coordination with others in relation to a specific biophysical setting, a flow of events, and a cultural repertoire, might combine with the concept of 'highly reliable' management of complexity (Roe 2013; Roe, Huntsinger et al. 1998) to open a space for dialogue with scholars and policy makers who are concerned with achieving system-level resilience. ${ }^{5}$

The conceptual model of small-scale, subsistence farming as a contingent, situated performance is probably not very useful very far beyond its domain. Richards said that the idea applies to "people-intensive small-scale farming systems" (Richards 1993: 72) - that is, situations where farmers have to negotiate and cooperate with others and participate in social processes, in order to achieve their farming goals. It would be largely unilluminating to apply it to the situations of large-scale, capital-intensive, industrialised farmers, who manage their farms as businesses, use tools and instruments such as laser-guided field levelling machines, integrate geospatial data harvested using drones and satellites, sign growers' contracts, purchase insurance, and so on. Though they are still susceptible to the vagaries of weather and markets, such farms are run much more like factories, according to management plans drawn up several seasons in advance. One would have to think carefully about the extent to which the performance concept is useful for understanding contract farming by small-scale outgrowers, where all the inputs and cultivation methods are directed by the company.

Approaching farming as a type of performance is certainly not the only way to study or analyse how farmers farm, or how farms operate as social-ecological systems. It may be fruitful, though it is beyond the scope of this article, to consider how the farming-as-performance approach might relate to or be connected or integrated with alternative conceptual frameworks. Other approaches in the political ecology, anthropology and rural studies literature are also agent-centred and sympathetic to the predicaments of small-scale cultivators, including the studies by Tania Murray Li (2014) on the emergence of capitalist relations of inequality among Indonesian highlanders, Akhil Gupta's (2017) exploration of the link between debt, neoliberalism and farmer suicides in India, or Shambu Prasad's (2016) examination of social innovation within rice farming networks in India. The performance lens may complement these, and it is particularly useful for thinking about how individual and collective resources of confidence, skill and knowledge, and social and material relationships are marshaled, connected and configured to create situated performances.

In terms of method, a difficulty for the observer is that the technical and social practices of individual and ensemble performance are often unconsciously realised and tacit. They emerge through practice, through relations among people and their interactions with their tools, materials and surroundings. Practices are often learned and expressed bodily, without necessarily being articulated verbally, and are engrained in a cultural habitus of which the performers themselves may not be explicitly aware. Paul Richards and his colleagues have proposed ethnographic approaches, specifically technography, which is designed to study practice and technique, the organisation of tasks and task groups, and the social and material interactions of practitioners (Arora and Glover 2017; Jansen and Vellema 2011; Maat 2018, Richards 2000). Technography is a methodologically eclectic but rigorous approach to observation, which can allow the researcher to develop a 'thin description' of the key components of social and technical practice, which include making (the transformation of materials); distributed cognition (the generation and distribution of information through task groups); and the rules, routines and protocols that arise from and govern the performance of tasks (Jansen and Vellema 2011). Examples of technographic studies undertaken by members of Richards' former group at Wageningen, which used the notion of performance as an analytical lens, include $\mathrm{PhD}$ theses by Adjei (2014), Sen (2015) and Ndubi (2015).

\footnotetext{
${ }^{5}$ I am grateful to a reviewer for encouraging me to emphasise this point.
} 


\section{References}

Adjei, B.E. 2014. The making of quality. A technography of small-scale women's groups and a medium-scale firm processing oil palm in Ghana. PhD dissertation. Knowledge, Technology and Innovation Group. Wageningen: Wageningen University.

Anderies, J. M., C. Folke, B. Walker and E. Ostrom 2013. Aligning key concepts for global change policy robustness, resilience, and sustainability. Ecology and Society 18(2): Art. 8.

Arora, S. 2017. Defying control: aspects of caring engagement between divergent knowledge practices. STEPS Working Paper 90. Brighton, UK: STEPS Centre.

Arora, S. and D. Glover 2017. Power in practice: insights from technography and actor-network theory for agricultural sustainability. STEPS Working Paper 100. Brighton, UK: STEPS Centre.

Bacon, C.M. 2010. Who decides what is fair in fair trade? The agri-environmental governance of standards, access, and price. Journal of Peasant Studies 37(1): 111-147.

Batterbury, S.P.J. 1996. Planners or performers? Reflections on indigenous dryland farming in northern Burkina Faso. Agriculture and Human Values 13: 12-22.

Bush, S.R. 2018. Understanding the potential of eco-certification in salmon and shrimp aquaculture value chains. Aquaculture 493: 376-383.

Callon, M. 1986. Some elements of a sociology of translation: domestication of the scallops and the fishermen of St Brieuc Bay. In J. Law (ed.). Power, action and belief: a new sociology of knowledge. London: Routledge \& Kegan Paul. Pp. 196-233.

Callon, M. 1987. Society in the making: the study of technology as a tool for sociological analysis. In W.E. Bijker, T.P. Hughes and T.J. Pinch (eds). The social construction of technological systems: new directions in the sociology and history of technology. Cambridge: MIT Press. Pp. 83-103.

Chambers, R., A. Pacey and L.-A. Thrupp (eds.). 1989. Farmer first: farmer innovation and agricultural research. London: Intermediate Technology Publications.

Dant, T. 2010. The work of repair: gesture, emotion and sensual knowledge. Sociological Research Online 15(3): $1-22$.

de Laulanié, H. 1992. Présentation technique du Système de Riziculture Intensive (SRI) basé sur le modèle de tallage de Katayama [Technical presentation of the System of Rice Intensification (SRI) based on Katayama's tillering model; photocopied typescript with manual corrections and annotations by the author]. CIIFAD SRI collection. Ithaca: Cornell University.

Flachs, A. 2018. Development roles: contingency and performance in alternative agriculture in Telangana, India. Journal of Political Ecology 25: 716-731.

Glover, D. 2011. A system designed for rice? Materiality and the invention/discovery of the System of Rice Intensification. East Asian Science, Technology and Society 5(2): 217-237.

Glover, D. 2014. Of yield gaps and yield ceilings: making plants grow in particular places. Geoforum 53: 184194.

Glover, D. and G.D. Stone. 2018. Heirloom rice in Ifugao: an "anti-commodity" in the process of commodification. Journal of Peasant Studies 45(4): 776-804.

Glover, D., J.-P. Venot and H. Maat. 2017. On the movement of agricultural technologies: packaging, unpacking and situated reconfiguration. In J. Sumberg (ed.). Agronomy for development: the politics of knowledge in agricultural research. London: Routledge. Pp. 14-30.

Goffman, E. 1959. The presentation of self in everyday life. New York: Doubleday.

Gupta, A. 2017. Farming as speculative activity: the ecological basis of farmers' suicides in India. In J. Heise, J. Christensen and M. Niemann (eds.). The Routledge companion to the environmental humanities. London: Routledge. Pp. 185-193.

Henke, C.R. 2000. Making a place for science: the field trial. Social Studies of Science 30(4): 483-511. 
Htwe, N.M., G.R. Singleton, L.A. Hinds, C.R. Propper and V. Sluydts 2012. Breeding ecology of rice field rats, Rattus argentiventer and $\underline{R}$. tanezumi in lowland irrigated rice systems in the Philippines. Agriculture, Ecosystems and Environment 161: 39-45.

Hutchins, E. 1995. Cognition in the wild. Cambridge: MIT Press.

Jansen, K. and S. Vellema 2011. What is technography? NJAS Wageningen Journal of Life Sciences 57(3-4): 169-177.

Lansing, J.S. 1987. Balinese 'Water Temples' and the management of irrigation. American Anthropologist 89(2): 326-341.

Latour, B. 2005. Reassembling the social: an introduction to Actor-Network Theory. Oxford: Oxford University Press.

Li, Murray T. 2014. Land's end: capitalist relations on an indigenous frontier. Durham: Duke University Press.

Maat, H. 2018. Group compositions: how policy and technology are implemented in smallholder farming. Journal of Political Ecology 25: 703-715.

Maat, H. and D. Glover 2012. Alternative configurations of agricultural experimentation. In J. Sumberg and J. Thompson (eds.). Contested agronomy: agricultural research in a changing world. London: Routledge. Pp. 131-145.

Mamidipudi, A. 2016. Towards a theory of innovation in handloom weaving in India. PhD dissertation. Maastricht: University of Maastricht.

Münster, D. 2018. Performing alternative agriculture: critique and recuperation in Zero Budget Natural Farming, South India. Journal of Political Ecology 25: 748-764.

Ndubi, J. 2015. Getting partnerships to work. A technography of the selection, making and distribution of improved planting material in the Kenyan Central Highlands. PhD dissertation. Knowledge, Technology and Innovation Group. Wageningen: Wageningen University.

Netting, R.M., M.P. Stone and G.D. Stone 1989. Kofyar cash-cropping: choice and change in indigenous agricultural development. Human Ecology 17(3): 299-319.

Richards, P. 1985. Indigenous agricultural revolution: ecology and food production in West Africa. London: Hutchinson.

Richards, P. 1986. Coping with hunger: hazard and experiment in a west african rice farming system. London: UCL Press.

Richards, P. 1989. Agriculture as a performance. In R. Chambers, A. Pacey and L.A. Thrupp (eds.). Farmer first: farmer innovation and agricultural research. London: Intermediate Technology Publications. Pp. $39-42$.

Richards, P. 1993. Cultivation: knowledge or performance? In M. Hobart (ed.). An anthropological critique of development: the growth of ignorance. London: Routledge. Pp. 61-78.

Richards, P. 2000. Food security, safe food: biotechnology and sustainable development in anthropological perspective. Inaugural professorial address, 22 June 2000. Wageningen: Wageningen University.

Richards, P. 2004. Private versus public? Agenda-setting in international agro-technologies. In K. Jansen and S. Vellema (eds.). Corporate responses to environmentalism, market opportunities and public regulation. London: Zed. Pp. 261-287. Google Books

Richards, P. 2006. The history and future of African rice: food security and survival in a West African war zone. Afrika Spectrum 41(1): 77-93.

Richards, P. 2015. The Good Seed. Why it may not be good, on a stormy planet, to leave everything to biotechnology. The Common Reader: A Journal of the Essay. May 8.

Richards, P. and G. Ruivenkamp 1997. Seeds and survival: crop genetic resources in war and reconstruction in Africa. Rome: International Plant Genetic Resources Institute (IPGRI).

Roe, E. 2013. Making the most of mess: reliability and policy in today's management challenges. Durham: Duke University Press. 
Roe, E., L. Huntsinger and K. Labnow 1998. High reliability pastoralism. Journal of Arid Environments 39(1): 39-55.

Schlanger, N. (ed.). 2006. Marcel Mauss: techniques, technology and civilisation. NewYork: Durkheim Press / Berghahn Books.

Sen, D. 2015. How smallholder farmers in Uttarakhand reworked the System of Rice Intensification: innovations from sociotechnical interactions in fields and villages. PhD dissertation, Knowledge, Technology and Innovation Group. Wageningen: Wageningen University.

Sen, D., H. Maat, D. Glover and C. Shambu Prasad 2017. The introduction of SRI in Uttarakhand, India: technopolitical mythologies and sociotechnical flexibility. Anthropologie et Développement (46-47): 101-127.

Shambu Prasad, C. 2016. Innovating at the margins: the System of Rice Intensification in India and transformative social innovation. Ecology and Society 21(4): article 7.

Shepherd, C. and A. McWilliam 2011. Ethnography, agency, and materiality: anthropological perspectives on rice development in East Timor. East Asian Science, Technology and Society 5(2): 189-215.

Shove, E., M. Pantzar and M. Watson 2012. The dynamics of social practice: everyday life and how it changes. London: Sage.

Sigaut, F. 1996. Crops, techniques, and affordances. In R. Ellen and K. Fukui (eds.). Redefining nature: ecology, culture and domestication. Oxford: Berg. Pp. 417-436.

Sigaut, F. 2002. Technology. In T. Ingold (ed.). Companion encyclopedia of anthropology: humanity, culture and social life. London: Routledge. Pp. 420-459. Scribd

Stengers, I. 2005. Introductory notes on an ecology of practices. Cultural Studies Review 11(1): 183-196.

Stone, G.D. 2007. Agricultural deskilling and the spread of genetically modified cotton in India. Current Anthropology 48(1): 67-103.

Stone, G.D. 2016. Towards a general theory of agricultural knowledge production: environmental, social, and didactic learning. Culture, Agriculture, Food and Environment 38(1): 5-17.

Stone, G.D. 2018. Agriculture as spectacle. Journal of Political Ecology 25: 656-685.

Stoop, W., N. Uphoff and A. Kassam 2002. A review of agricultural research issues raised by the system of rice intensification (SRI) from Madagascar: opportunities for improving farming systems for resourcepoor farmers. Agricultural Systems 71(3): 249-274.

Suchman, L.A. 1987. Plans and situated actions: the problem of human-machine communication. Cambridge: Cambridge University Press.

Uphoff, N. 2002. Opportunites for raising yields by changing management practices: the System of Rice Intensification in Madagascar. In N. Uphoff (ed.). Agroecological innovations: increasing food production with participatory development. London: Earthscan. Pp. 145-161.

Vasavi, A.R. 2012. Shadow space: suicides and the predicament of rural India. Gurgaon, IN: Three Essays Collective.

Wenger, E. 2000. Communities of practice: learning, meaning, and identity. Cambridge: Cambridge University Press. 